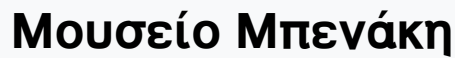

A Singular Antiquity: Archaeology and Hellenic Identity in Twentieth-Century Greece

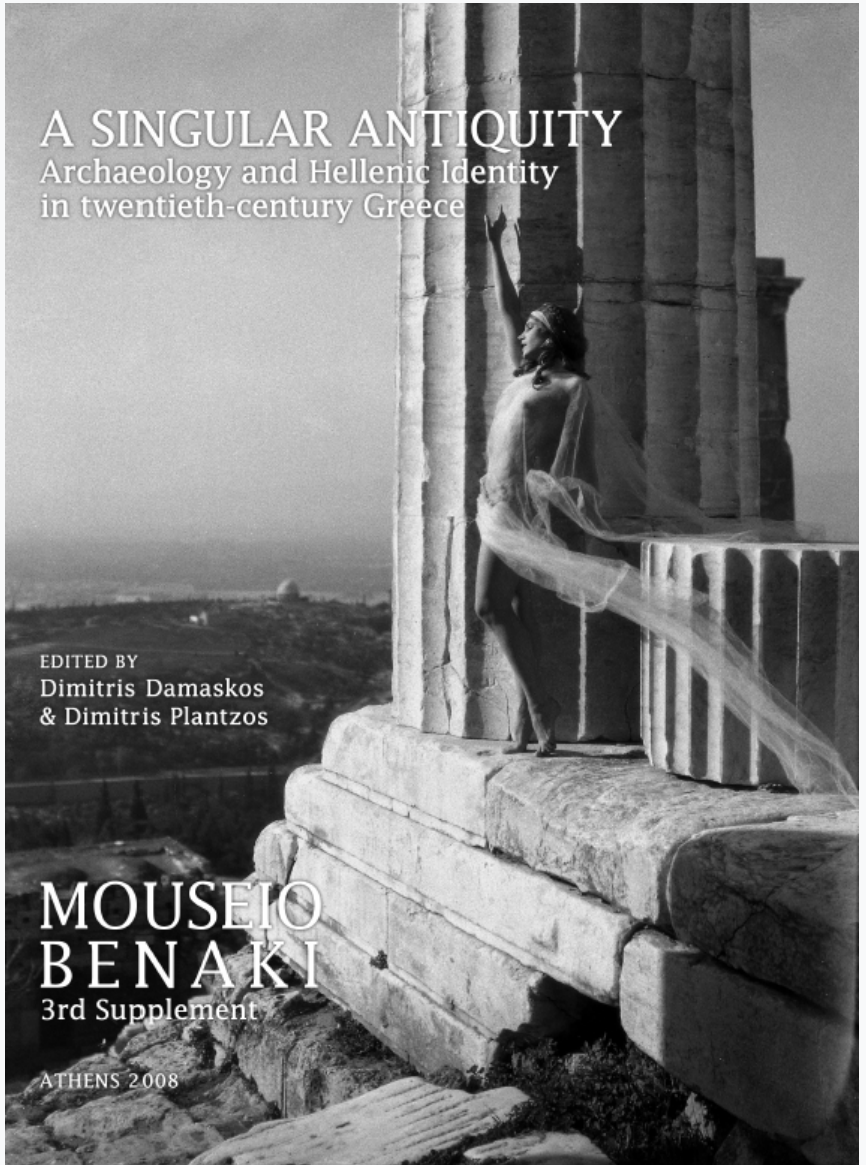

Archaeology, nationalism and the land in modern Greece

Mark Mazower

doi: $10.12681 /$ benaki.17970

Copyright (C) 2018, Mark Mazower

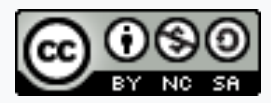

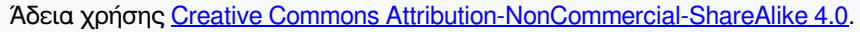

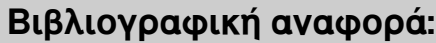

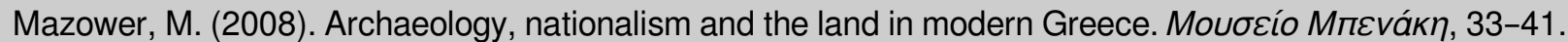
https://doi.org/10.12681/benaki.17970 


\section{Archaeology, nationalism and the land in modern Greece}

The 1837 CONSTITUTION of the Athens Archaeological Society provides ample evidence for the tight relationship between archaeology, nationalism and the land. 'The liberation of Greece', reads the opening preamble, 'was an event not merely joyful for any philanthropic and noble heart but also of the greatest importance for history and archaeology upon which a new light has unexpectedly been poured. Enslaved and half-dead, Greece had been forgotten and extinguished from the chronicle of Nations'. Despite the efforts of foreign antiquaries, it went on, 'the ignorance and barbarism' of the despotic Turks prevented proper enquiry. Since Liberation, the Greek Government has promoted excavations, but could do with assistance, since: 'The Greek soil, however, is an inexhaustible source of archaeological wealth and many historical truths, and many examples of beauty and nobility of spirit lie buried therein'. ${ }^{1}$

Founded in order to 'enrich Knowledge' and in particular to encourage the excavation, restoration and sympliroseis of 'ancient Hellenic monuments', the Society would seem to have been an integral element of the new rapprochement between archaeology and nationalism. Modern nationalism in general directed its gaze towards the acquisition of land, its surveying and settlement by the members of the Nation. In the nineteenth century and first half of the twentieth, national states fought wars to expand - more land was better than less - and to revive in the political institutions of the present the glories of the national past. The simultaneous emergence of the politics of nationalism, on the one hand, and the practice of archaeology on the other was no coincidence. History - and above all, especially in the Greek case, archaeology - served to justify the new ter- ritorial possessions, and to demonstrate that the credentials of the Nation lay buried within them. Carl Schorske has aptly described the nineteenth century as the age of 'thinking with history', ${ }^{2}$ and nowhere in Europe showed a tighter connection between politics and historical consciousness than Greece. It would scarcely be exaggerating to argue that the country owed its independence to Europe's identification of itself with the ancient Greeks, and to its identification of the Ottoman Empire with barbarism. If care for the past allowed states to assert their modernity, in proving how seriously it took its charge over that past from which modern Europe derived its sense of itself, then the new Greece would prove that European Philhellenism had not been misplaced. ${ }^{3}$ And at the same time, it would demonstrate its responsibility towards its own ancestors. 'The preservation and excavation of whatever survived the years under barbarian rule', wrote Moustoxidis in 1829, was essential to the nation's self-respect. ${ }^{4}$

Thanks to the recent work of a number of scholars, archaeology's complicity in Greek nationalism has become widely recognized. We see the propaganda value of, say, Andronikos' digs, the key contribution made by archaeologists to the hellenization of the landscape through place-name committees that replaced 'barbarian names' with new or old Greek ones. 'We have come to understand the struggle to bring other pasts - in particular Byzantium and the Franks - into the picture, and to turn a historical narrative of ellipses into one of continuities. Above all, we have come to understand how archaeology could make - or appear to make - the difference in disputes over territorial ownership and jurisdiction. Dimitsas asserted the 
usefulness of his pioneering 1896 study of Macedonia on the grounds that it would stimulate 'a sense of the legal ownership of the land in the hidden testimonies of its Greekness'. ${ }^{6}$ However, the Great Powers chose to interpret the wishes of the land's current inhabitants, they would surely heed the message of its stones. Excavation established identity, furnished the young state with its most potent symbols and provided the material to 'demonstrate that the inhabitants of Greece are descendants of the ancient Greeks.?

And as E. Bastéa, ${ }^{8}$ A. Karadimou-Yerolympou' and other urban historians have demonstrated, the fruits of that excavation helped shape the modern country too, and allowed its newly-planned towns and cities to demonstrate their rupture with Ottoman backwardness. War-ravaged towns were rebuilt in the Neoclassical mode in the plains, leaving older medieval settlements stranded on hillsides, such as at Corinth, Sparta, and Syros. The new capital was chosen for its classical associations, replacing the old Ottoman provincial administrative centres, which were quickly marginalized. I need only to refer to Thessaloniki, whose mixture of Haussmanism and neo-Byzantium welded early twentieth-century modernity with another national inheritance.

Yet compelling though this picture - of a national movement inextricably intertwined with the politics of the past - is, were not things perhaps just a little more complicated? It is with something of a shock that one tries, for instance, to reconcile the current view of archaeology as the handmaiden of nationalism with the way things looked (and perhaps still do) to the archaeologists themselves. Athens may stand out as the prime example of how a state could press scholarship into political service and instrumentalize both history and archaeology, but let us view things for a moment from the other side. The state may make claims based on archaeological finds to new land but what of the land in its possession, or possessed by private landowners? The history of archaeology is - after all - a long tale of arguments and fights over who controls the land and which of its many functions should take precedence over the others. In the 1840 s and 1850 s the Archaeological Society at Athens had to buy much of the land - often privately held - on which it wanted to dig, and its chronic financial problems, unsolved even after the state allowed it to arrange a lottery, forced it to sell off to builders the stones of the medieval and Otto- man buildings it was demolishing on the Acropolis. ${ }^{10}$ The clash between the diggers and scholars, on the one hand, and the real estate developers, or simply property owners, on the other hand, thus goes back all the way to the start of the Greek state and then forward, as Michael Herzfeld demonstrated so beautifully in his book on Rethymnon, ${ }^{11}$ into the present. In this context, at least, the appeal to nationalism can be construed as a legitimizing slogan by a scholarly community all too conscious of its own feeble standing in daily life rather than a self-evident truth of unstoppable force; and all the more so as what it is to be an archaeologist - sociologically, intellectually - changes so fast between 1830 and 1950 .

Is it not, too, a symptom of the basic weakness of the archaeologists as an organized political force, that their moments of greatest opportunity have often turned out to be in the aftermath of national or local disasters - fires, earthquakes and wars, in particular - when the normal life of built-up areas is temporarily suspended, and for a moment, local authorities are forced to cede some of their power - which is usually deployed as effectively in blocking the archaeologists as in helping them - to other, more sympathetic political forces? What kind of force have archaeologists constituted institutionally, and what precisely has been their relation over time with the Greek state, or its investments in them? Take perhaps another sign of weakness, of insufficient personnel in the face of resourceful local opposition - the extraordinarily long time spans of some major digs, especially in urban centres - the Athens Agora or the palace complex in Thessaloniki?

If, in other words, we are interested in the relationship between nationalism and archaeology, maybe we should ask: at what points has archaeology played a prominent role in shaping Greece's national image? What kinds of archaeology, with what sorts of goals have been involved over time? And how have changes in the national iconography been affected by the development of institutional, professional, aesthetic and other factors?

The Neoclassical vogue which led to Athens being made capital of the new state, and which lay behind the formation of Greece's earliest archaeological society, was not an unqualified success. To be sure, it led to the demolition of the Frankish tower on the Acropolis in 1874, and to the destruction of numerous Byzantine churches in the old town on its slopes at the same time. It was certainly not until the next century that the historians' arguments 
for taking Byzantium seriously as a valuable part of the national heritage achieved significant institutional success with the formation of Ephorates of Byzantine monuments and, belatedly, a Byzantine museum in Athens (and that in the supposed centre of Byzantine art - Thessaloniki - had, of course to wait for very much longer). Yet the state was not willing to invest much in archaeology of any kind for several decades - the Athens Society went bust in the 1850 s before state aid revived its fortunes.

Moreover, while clearly serving - or more precisely, seeking to serve - national goals, archaeology in the midnineteenth century was at the same time an intensely and increasingly inter-national discipline. Archaeology's very emergence as a professional discipline involved complex linkages between Greece and the Great Powers - France, Britain and above all Germany. An implicit and often tense bargain underpinned this: access for foreign archaeologists, through foreign schools, to Greek soil in return for contact with the centres of the evolving scholarship and conformity with its new standards and practices. Neocolonialism? Perhaps. But Greece was a pioneer in establishing state control over the licensing of rights to excavation. There was a quiet bargain implicit in the way Prince George had no sooner landed in Ottoman Crete as High Commissioner - in a deal brokered by the Great Powers that kept the island nominally under the Sultan - than he was dishing out permits to Greek and foreign archaeologists alike. In other words, Greece benefited too from the international character of the discipline which allowed it to elaborate an implicit (and often) claim to a more far-reaching Hellenism, through its promotion of archaeological research into the classical past well outside the borders of the 1830 state, in the Turkish and Arab lands of the eastern Mediterranean. Greek archaeologists did pretty well, after all, in the struggle against the Germans for the excavation rights in what was still nominally Ottoman Samos in 1902, a struggle in whose resolution Themistokles Sofoulis - Professor of Archaeology at Athens University and a future prime minister - played a key role both politically and as eventual excavator of the Heraion. ${ }^{2}$

The role played by foreigners in the identification and collection, and often looting, of antiquities was always a contentious subject in Greece. ${ }^{13}$ Nevertheless, it does not seem to have possessed the political importance in the nineteenth century that it did in the twentieth. It was the latter that fully revealed the limits to archaeological inter- nationalism. As Richard Clogg and others have shown, archaeologists were always natural spies: their knowledge of the language and the terrain, their surveying skills and experience as travellers, made them valuable commodities in times of war. We could go back - if not to Cyriac of Ancona - then certainly to Leake, for examples. But it was the two World Wars that demonstrated the dangers - in an age increasingly obsessed with national security. One thinks of Wace, Hasluck and Mackenzie sitting in the British School in 1915, compiling their catalogue of suspect persons; or Walter Wrede, in 1941, combining his duties as local Nazi Party leader and archaeologist at the German Archaeological Institute, showing an appreciative Himmler around the Acropolis. As a result, I think, archaeology became more national, or at least less international - even as it became more professionalized - after World War I. The growth and reach of the Greek state - with such far-reaching effects in so many areas of life - affected archaeology too, and led to an unprecedented expansion of museums, personnel and publications.

The Neoclassical focus of nineteenth-century Greek archaeology also faced stiff competition in setting the visual and iconographic agenda - something I would like to dwell on here. In representations of the Greek landscape, Bavarian and French Neoclassicism was quickly left behind by the vogue for Romanticism. As the age of steam brought unprecedented numbers of travellers to see the Greek sites, the illustrated guidebooks and travel accounts they read presented the past and present Greek lands according to the rules of the picturesque. The monuments of the past were on prominent display, but in accordance with the dictates of taste, they were shown crumbling and in ruins, an explicit contrast with the signs of a decaying and wretched present. Enlivening the scene, and pointing the contrast there would be a lone shepherd and his grazing sheep, or maybe a guard, or even fustanella-clad tomb-robbers (fig. 1). Occasionally, the artist would portray himself in a quiet corner sketching. What devotees of the picturesque sought were the quiet signs of antiquities before the archaeologists had got to them, or at any rate, before they had time to do much in the way of clearing things away, scrubbing them clean, still less restoring them. Ruins were thus a kind of memento mori - and certainly not any kind of vindication of the present and its political organization.

A typical example - but just one of thousands - is the 


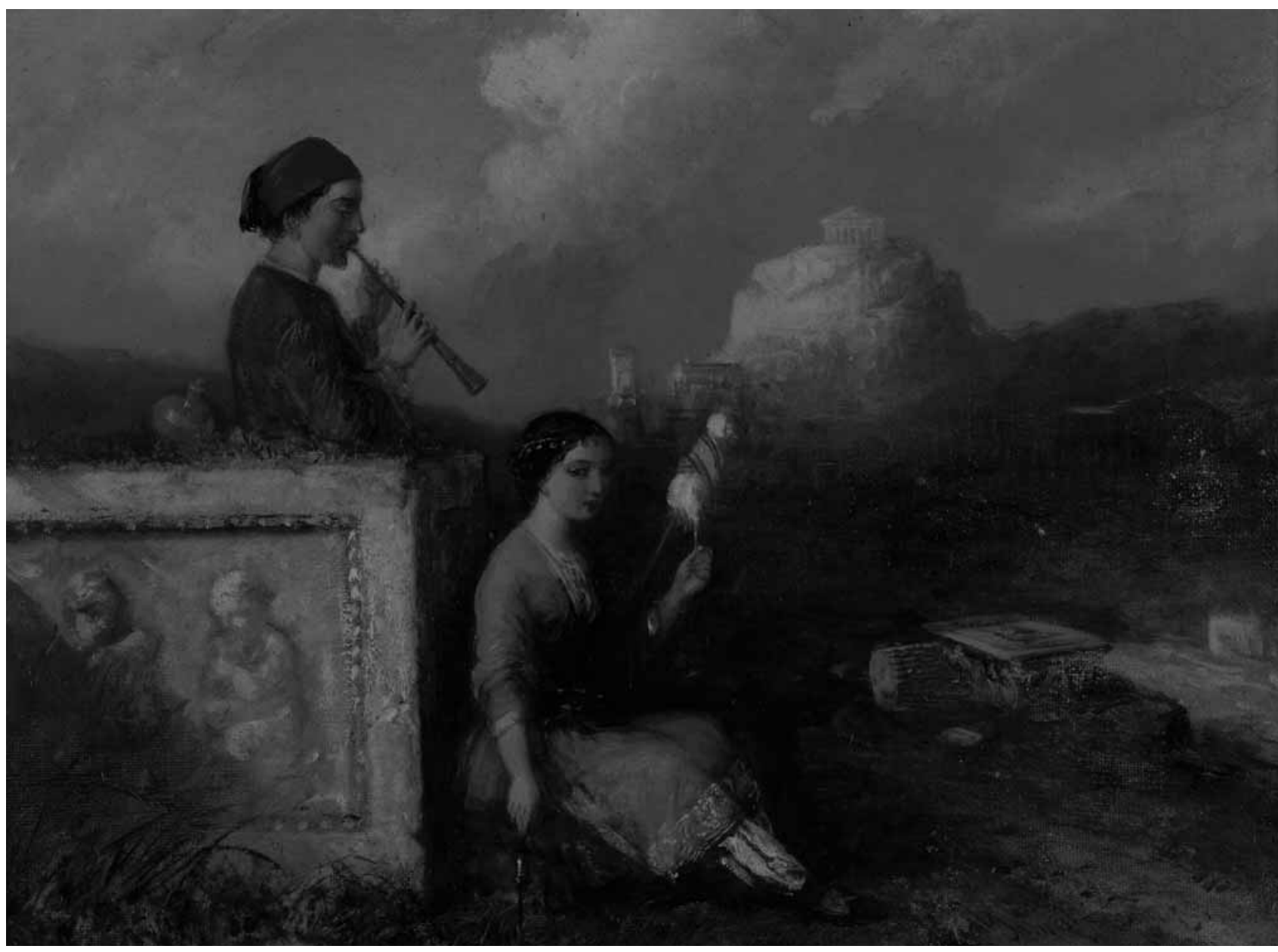

Fig. 1. J. Linton, A Greek Couple (ca. 1860). Athens, Benaki Museum inv. no. 9006.

view of the entrance to the Acropolis in du Moncel's Vues pittoresques des monuments d'Athènes (fig. 2): ${ }^{14}$ the setting sun casts a long shadow over the foreground, in which a few stray onlookers stand amid the boulders and debris of the still unrestored pathway up. Above them looms the dark mass of the Frankish tower, not yet demolished; its tip, like the columns of the Propylaea itself and the Temple of Athena Nike to the side, is jagged and incomplete. Like Baalbek for Volney - the locus classicus of this trope - the half-eroded columns of the classical past merely point up the woeful inadequacy of the present.

Nor did the rise of new artistic technologies mean the end of this aesthetic. On the contrary, as photogravure (with its incomparable ability to reproduce fine gradations of tone) and then photography replaced etchings as the preferred medium of mechanical reproduction, the picturesque gained a new lease of life. In the works of the most important and prolific illustrator of Greece at the start of the twentieth century, the Swiss Philhellene Fred Boissonnas, the picturesque predominates. A black-coated shepherd tends his sheep in the fields to the south-west of the Acropolis which looms over him; in the middle ground, some nondescript modern stone buildings form a salutary contrast with the Parthenon behind them (fig. 3). This is not the site of Hellenism divorced from the present; quite the contrary. Indeed the present entered the work of the photographers even more systematically than it had the engravers'. Perhaps encouraged by the nature of their craft, they saw themselves as recorders of tradition, creators simultaneously of an ethnographic as well as a monumental archive: for them, above all, the present of Greek life, especially but not only in the countryside, 


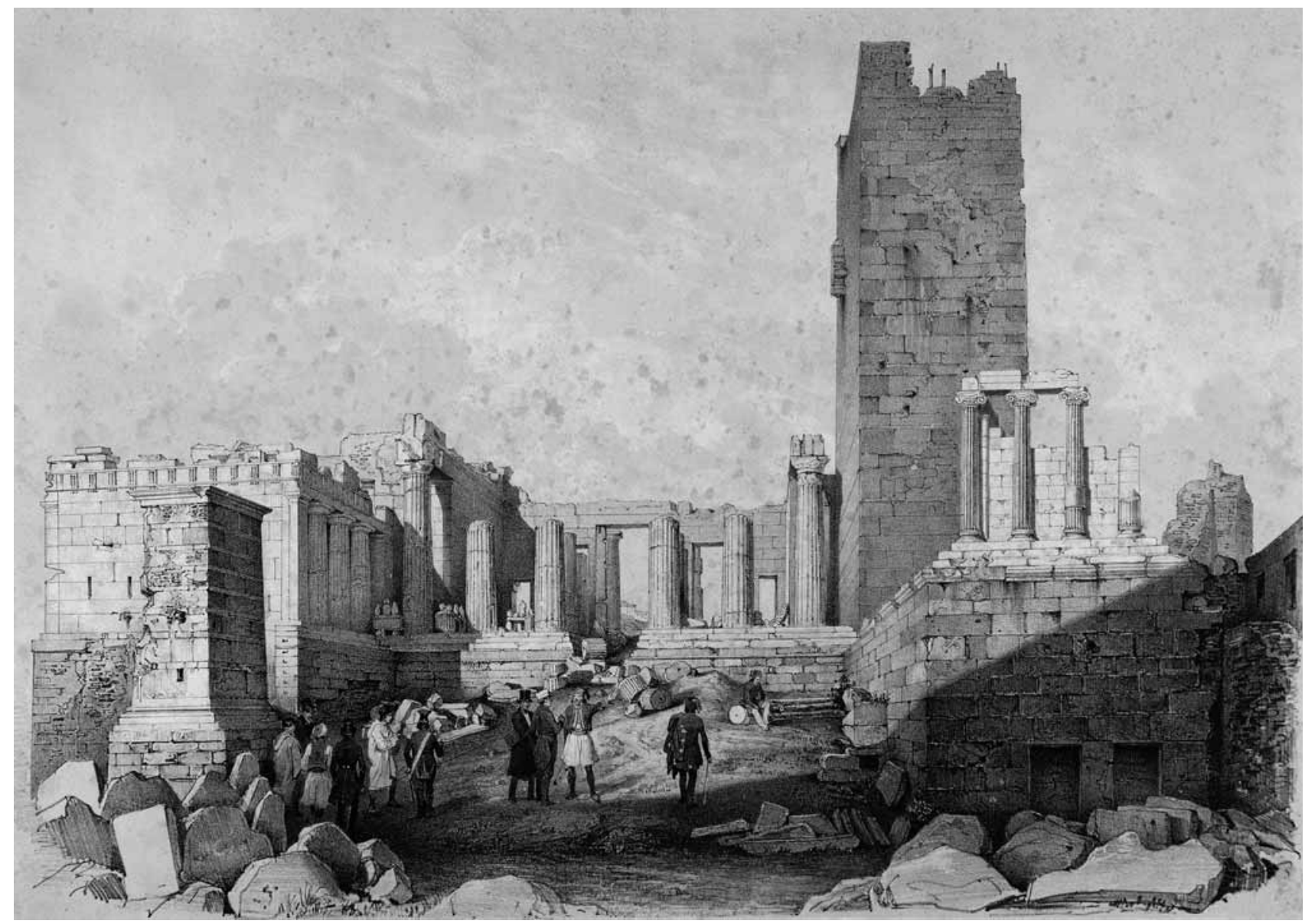

Fig. 2. T.-A.-L. du Moncel, plate from Vues pittoresques des monuments d'Athènes (Paris 1846).

could be linked to the classical past. Byzantine monasteries, harvesting peasants, even usually a few Ottoman mosques, bridges and tekkes, may be glimpsed alongside the classical past. Archaeological knowledge informs the landscape of Greece as presented in these works but does not entirely shape it. Picturesque and ethnographic exactitude both encourage the fin-de-siècle photographer to train his or her lens on the present as well as the past, town as well as country. Greece's primary claim might remain its ancient monuments, but that certainly did not lead editors and compilers to ignore much that advocates of classicism found repugnant: the Baba mosque in Thessaly was much admired as an example of the picturesque - few sights were more poignant by the early twentieth century to the European imagination than the now-faded remnants of a oncepowerful Muslim empire; so too was the Vale of Tembi, a favourite scene for artists right up until World War I, but scarcely visited after that.

For a break occurs with the Great War. Even as archaeology achieves new purchase in the state and the universities, specializes and extends its reach into the Byzantine and later epochs, so its influence grows in the visual and representational realm as well. In the twenties, so Tziovas and others have shown us, ${ }^{15}$ the aftermath of the Asia Minor Catastrophe and the collapse of the Megali Idea lead to an assertion of Hellenism in the realm of cultural politics. Such schlocky aestheticizing productions as Vera Willoughby's Vision of Greece - which depicts 'the pure essential Hellas' as a 'vision [...] in the web of sleep', 'radiant, ever-changing but unchanged', 'a type of that empire of the mind, the dream that is a reality' - merely push to a crass extreme some of the impulses that motivated much 


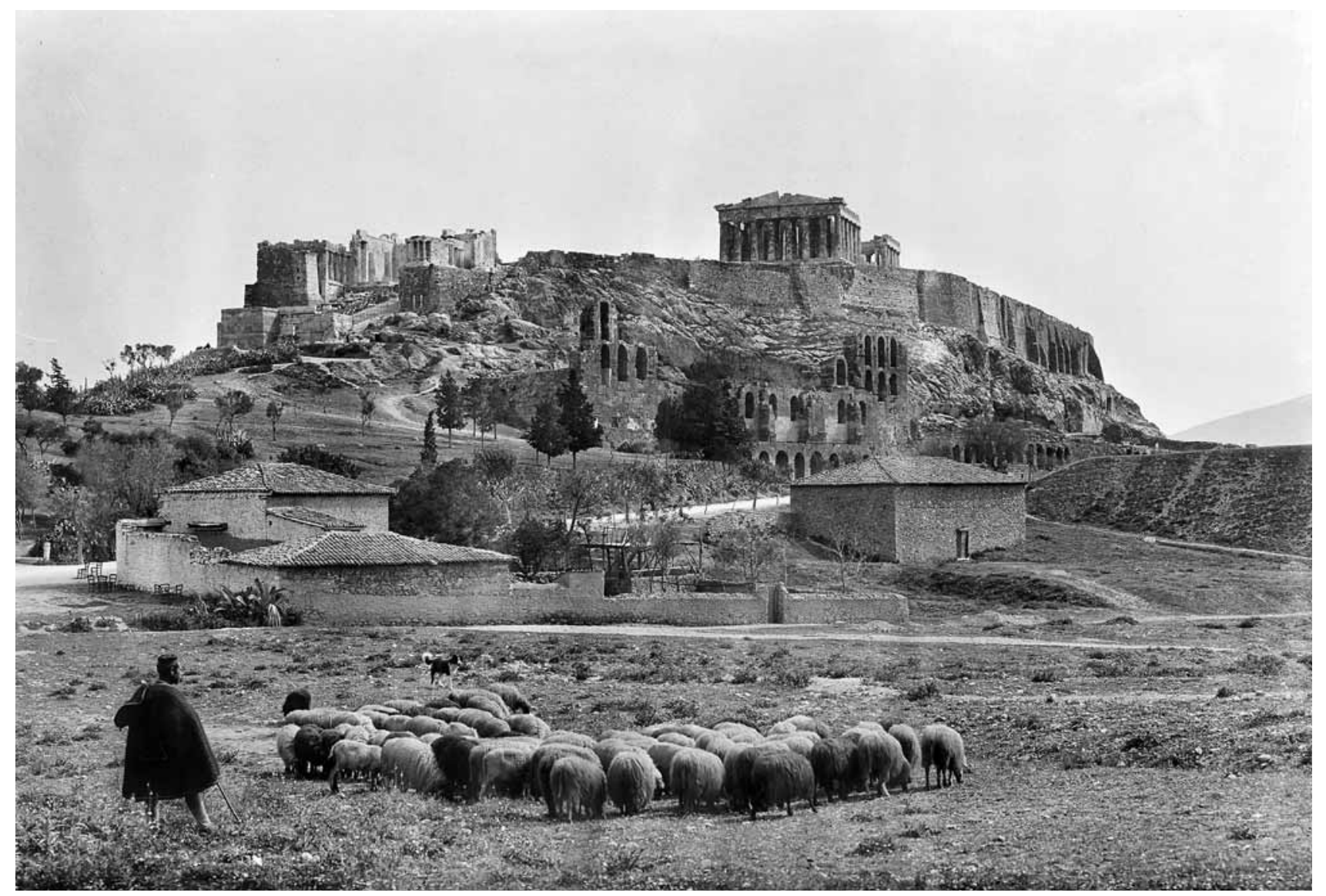

Fig. 3. F. Boissonas, The Acropolis from the southwest, 1903(?) (photo: ๑Fred Boissonas Photographic Archive, Hellenic Culture Organization/Thessaloniki Museum of Photography).

more serious work, inside Greece as well as outside. Athens, writes Willoughby, 'still lives, still draws to herself the souls of those who do not see the modern travesty that bears her name' - a sentiment that, in its anti-urbanism, its refusal to acknowledge present changes and present challenges encapsulates the spirit of the new Neoclassical outlook. ${ }^{16}$

In this view of things, under the sign of a different aesthetic, the ruins of Greece play a very different role. Now, thanks too to the work of archaeologists, who have cleared away their surroundings to allow them to be the more properly viewed, cleaned them up and started systematic 'restoration', the ruins figure as emblems of a kind of eternal perfection. There are stark contrasts, not subtle tints, and human onlookers are not wanted. Rather we are in, or close to, the territory of 'Eternal Greece', visible in the schizophrenic art of Nelly (whose Greek refugees seem to inhabit an entirely different universe), and more commer- cially, in the fashion shots of George Hoyningen-Huene, pioneers in the combining of beautiful bodies with classical statuary. In this idealized and rarified landscape, there are no cities or villages. Hellenism means columns, rocks and the sea - the visual equivalent to Seferis' 'King of Asine' in other words. The ethnographic and the picturesque are banished, perhaps because they would provide too painful reminders of the struggles and violence of the present. The worse things get, the more Greece is stripped of its history. Thus the apotheosis of this approach emerges during the German occupation with the publication of works like the 1943 Hellas, or the prolific Martin Huerlimann's 1944 photo-album Ewiges Griechenland published in Zurich.

By the end of the war, the trope had become such a cliché that that old agent provocateur, the cartoonist Osbert Lancaster, could not resist making fun of it. In his Classical Landscape with Figures, first published in 1947, 
he draws on his own experiences in Athens with the British Army during the early days of the civil war to offer a gentle but pointed critique of Neoclassicist excesses: 'By what right, it may be argued, does a landscapist concern himself with humanity at all? The presence of a picturesque peasant tastefully draped on a broken column in the middle distance is perhaps allowable, but why is the whole foreground cluttered up with a heterogeneous collection of human oddities whose generally unromantic aspect fits them only for appearance in a newsreel?' And yet the war and politics had brought past and present ever closer together. 'The Cyclopean masonry of the Mycenaean strong-point has been re-erected to protect an Axis gunpoint and the mortar batteries of ELAS have left scars on the Acropolis'. He failed, to be sure to mention that ELAS had been targeting the British gun emplacements there but did criticize Metaxas for tidying up the approach to the site. As for the archaeologists, Lancaster was scathing. Their 'learned vandalism' had wreaked havoc in Athens and at Delphi: 'the average archaeologist of any nationality being almost invariably deficient in visual sense, is about as safe a person to have around a well-conducted city as a bomber-pilot or a by-pass builder. ${ }^{17}$

Yet despite Lancaster's scorn - and not only his (the American destruction of the old houses in the Athenian Agora in the fifties did not go unprotested ${ }^{18}-$ the hegemony of Neoclassicism in representations of Greece if anything intensified after the war. Before the war, aesthetic impulses had fuelled its rise and connected it with the wider Neoclassical revival visible across the European arts and across the political spectrum from modernizers like Picasso and Stravinsky, through Matisse to traditionalists like Maillol, Arno Breker and (in architecture) Albert Speer. Closely connected to the struggle between Modernism and its enemies, Neoclassicism had appealed to both. After the war, it seems to me, its continued appeal and its ideological adaptability reflected converging political and economic trends. As mass tourism met high-prestige state-sponsored excavations, post-war archaeology entered the service of the national state as never before. In the case of Israel one thinks of the vital importance of the 1966 Masada exhibition; ${ }^{19}$ for Greece, through the publicity given to finds by Marinatos and above all Andronikos at Vergina.

Mass tourism too helped the canonization of the highly idealized Neoclassical aesthetic which had emerged between the wars. Widely selling glossy photo-albums enticed would-be or armchair travellers to the destinations being developed by the Greek National Tourism Organization (EOT).$^{20}$ Focusing on sea, sand and bodies, on Athens, the islands, Delphi and the Peloponnese, they excluded much of the country and much of its past far more decisively than their early twentieth-century predecessors had done. Eternal Greece was confined to what could most easily be accessed through new travel agencies by bus from Athens or boat from Piraeus. In this way the economies of scale offered by mass tourism shaped postwar representations of the country and accentuated the flight from history. Northern Greece was particularly marginalized, as were those archaeologists trying to push the national consciousness towards the preservation of Byzantine or even later antiquities. Ottoman and Neoclassical mansions fell into decay or were turned into polykatoikies. The countryside emptied out, and land in the cities became more valuable than ever before as they boomed. But none of these changes - perhaps the most dramatic in the country's recent social history - could have been guessed by perusing the increasingly luxurious publications of EOT or its foreign counterparts.

So: archaeology in the service of tourism and the national economy? To some extent, yes. But we should not forget that tourism, property speculation and town planning was often also acting against what archaeologists saw as their interests and ignoring their priorities. The marketing men at the Ministry of Tourism wanted purity; but the archaeologists wanted to emphasize change and saw the 'quest for purity' as old-fashioned, an impulse of architect-restorers in the twenties who had done more harm than good (men such as Zahos in Thessaloniki, responsible for largely rebuilding Agios Dimitrios). Prestige projects went ahead in high-profile locations. Everywhere else? A generally different story.

And today? Confirmation, surely, that there is no fixed identity between the needs of power and the archaeological profession. Archaeology has changed enormously, even in the past thirty years. The spread of field surveys, industrial and ethno-archaeology and the boom in museology have diffused the discipline's offerings and led it to sponsor a much wider and more inclusive conception of the past than it once did. The political elite, having grown up on the ideology of Eternal Greece, finds it hard to let go. Substantial restoration work at Mistra began only in the eighties though the results were striking enough by 
the late nineties for the inhabitants of Sparta to start complaining that their antiquities were being neglected. But changes in tourism itself - the rise of a heritage industry, and the response to the demand for 'traditional accommodations' - have improved the protection for post-Byzantine architecture. The nineties also saw a new interest in urban renewal - driven by access to plentiful EU funds - through which entire neighbourhoods (the Ano Poli, or the Ladadika in Thessaloniki formed part of one ambitious project) are now protected as part of the national heritage. Thus driven, on the one hand, by autonomous trends within the disciplines of archaeology, conservation and urban planning, and on the other by market responses to economic opportunity, these new developments constitute a major challenge to the Neoclassical model of Greek national identity. They have certainly not swept all before them. Outside the major tourist centres, older criteria remain in play, the archaeological services remain over-stretched and under-funded and key monuments such as the frescoed mansions of Siatista crumble into dust. The preservation of key Ottoman sites lags a long way behind, though often the real difficulties seem to lie in working out arrangements for their use rather than in acknowledging their historical value. But here too the market has intervened in combination with the state, as in the recent restoration of Mehmet Ali's Imaret in Kavala, turned now into a luxury hotel after careful consultation with the archaeological services.

All of this suggests to me that, as I indicated at the start, the nature of the connection between archaeology and nationalism needs to be carefully specified. Looking over the entire span of the history of Greece since the 1830s, there has been no simple instrumentalization of scholarship. The scholarship itself has changed, as has its institutional and political reach. Aesthetic and other influences often shaped cultural practice independently of political demands. To be sure, key political choices in the early years of the new state were clearly bound up with attitudes to the classical past. And in the middle of the twentieth century, roughly between 1920 and 1975, a series of political elites reorganized the state, sponsored the development of both archaeological preservation and tourism promotion, and drew more heavily than ever before - or perhaps after - upon the country's archaeological riches to create a kind of nationalist iconography. But Eternal Greece too now seems to have had its day.

\section{Mark Mazower}

Department of History

Columbia University

mm2669@columbia.edu

* The editors wish to thank Dr Fani Maria Tsigakou (Benaki Museum), Dr S.I. Arvanitopoulos (Museum of the City of Athens) and Dr I. Papaioannou (Photography Museum of Thessaloniki) for their kind collaboration in providing the photographs in figures 2 and 3.

\section{Notes}

1. Petrakos 1987, 214.

2. Schorske 1998.

3. Cf. Skopetea 1988, 161-247.

4. Kalogeropoulou \& Prouni-Filip 1973, o $\gamma^{\prime}$; and, in general, $v \zeta^{\prime}-\pi \theta^{\prime}$; also Kokkou 1977, 47-68. See also Peckham 2001, $115-22$.

5. Cf. Herzfeld 1991; Kotsakis 1998; Hamilakis \& Yalouri 1996; Peckham 2001, 35; 139-42; Herzfeld, this volume.

6. Dimitsas 1896; Kofos 1990, 103-41.

7. Peckham 2001, 119.

8. Bastéa 2000.

9. Karadimou-Yerolympou 1995.

10. Petrakos 1987, 26-27.

11. Herzfeld 1991.

12. See Kalpaxis 1990.

13. See Kalogeropoulou \& Prouni-Filip 1973, $\lambda \varsigma^{\prime}-\mu^{\prime}$.

14. Théodore-Achille-Louis Du Moncel, Vues pittoresques des monuments d'Athènes. Collection composée de quatorze grandes planches lithographiées, d'un panorama de la ville, et d'un texte explicatif avec gravures sur bois (Paris, Victor Delarue, 1845).

15. Tziovas 1989. 
16. Willoughby 1925,$5 ; 23$.

17. Lancaster 1974,$9 ; 43 ; 49$.

18. Sakka, this volume.

19. Its designer, the Warsaw-born British designer, George
Him, had designed the first-ever Holocaust exhibition - the 1961 Warsaw Ghetto Exhibition - before designing the Masada exhibition of recent finds there for The Observer.

20. See recently EOT 2007.

\section{REFERENCES}

Bastéa E. 2000: The Creation of Modern Athens: Planning the Myth (Cambridge).

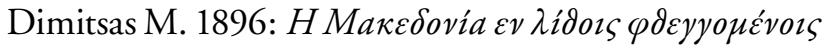

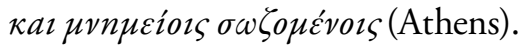

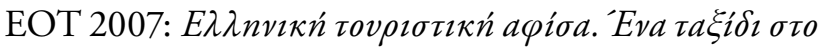

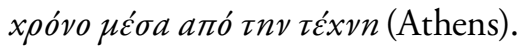

Hamilakis Y. \& Yalouri E. 1996: Antiquities as symbolic capital in modern Greek society, Antiquity 70, 117-29.

Herzfeld M. 1991: A Place in History: Serial and Monumental Time in a Cretan Town (Princeton).

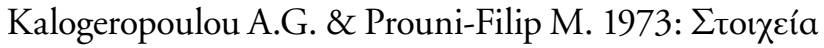

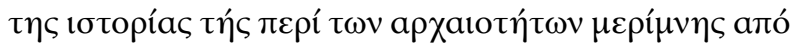

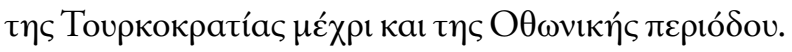

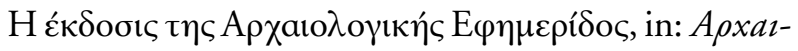

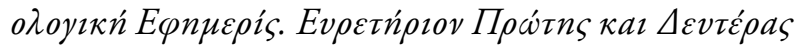

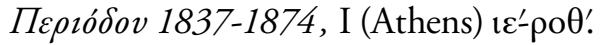

Kalpaxis Th. 1990: A

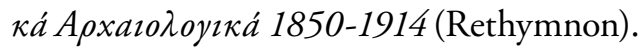

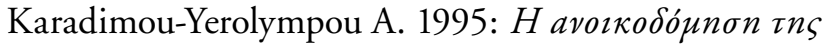

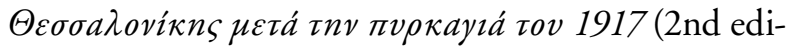
tion; Thessaloniki).

Kofos E. 1990: National heritage and national identity in nineteenth- and twentieth-century Macedonia, in: Blinkhorn M. \& Veremis Th. (eds), Modern Greece: Na- tionalism and Nationality (London and Athens) 103-41.

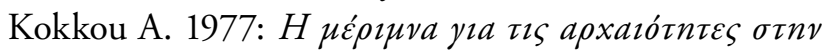

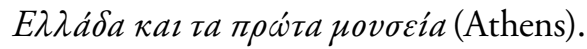

Kotsakis K. 1998: The Past is Ours: images of Greek Macedonia, in: Meskell L. (ed.), Archaeology under Fire: Nationalism, Politics and Heritage in the Eastern Mediterranean and Middle East (London and New York) 44-67.

Lancaster O. 1974: Classical Landscape with Figures (2nd edition; London).

Peckham R.S. 2001: National Histories, Natural States: Nationalism and the Politics of Place in Greece (London and New York).

Petrakos V. 1987: H عv Adńvaıs A

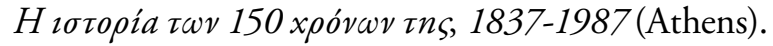

Schorske C.E. 1998: Thinking with History: Explorations in the Passage to Modernism (Princeton).

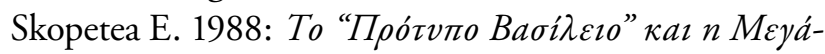

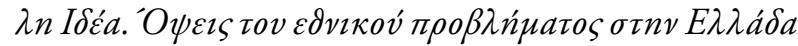
(1830-1880) (Athens).

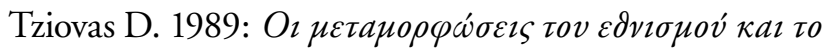

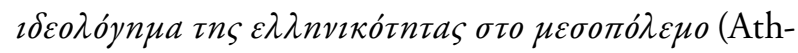
ens).

Willoughby V. 1925: A Vision of Greece (London). 
